\title{
State-run media outlets in Central Asia: external regime legitimation through regional conflict and cooperation framing
}

Article

Accepted Version

Pak, M., Menga, F., Feuer, D. and Dowell, A. (2020) State-run media outlets in Central Asia: external regime legitimation through regional conflict and cooperation framing. Central Asian Survey, 39 (3). pp. 378-397. ISSN 1465-3354 doi: https://doi.org/10.1080/02634937.2020.1781060 Available at https://centaur.reading.ac.uk/91175/

It is advisable to refer to the publisher's version if you intend to cite from the work. See Guidance on citing.

Published version at: https://www.tandfonline.com/doi/full/10.1080/02634937.2020.1781060? instName=University+of+Reading

To link to this article DOI: http://dx.doi.org/10.1080/02634937.2020.1781060

Publisher: Taylor \& Francis

All outputs in CentAUR are protected by Intellectual Property Rights law, including copyright law. Copyright and IPR is retained by the creators or other copyright holders. Terms and conditions for use of this material are defined in the End User Agreement. 


\section{CentAUR}

Central Archive at the University of Reading

Reading's research outputs online 


\title{
State-Run Media Outlets in Central Asia: External Regime Legitimation Through Regional Conflict and Cooperation Framing
}

\author{
Authors: Mariya Pak $^{*}{ }^{*}$, Filippo Menga ${ }^{\mathrm{ii}}$, Daniel Feuer ${ }^{\mathrm{iii}}$, Austen Dowell ${ }^{\mathrm{i}}$ \\ This is an Accepted Manuscript of an article published by Taylor \& Francis in Central Asian \\ Survey [Article DOI 10.1080/02634937.2020.1781060].
}

\begin{abstract}
In this article, we empirically examine how the Central Asian states apply external regime legitimation strategies to legitimize their regimes domestically. We used the Central Asia Watch Project's data from five Central Asian state-run media outlets to examine spatial and temporal changes in applying regime legitimation strategies. The results show that all Central Asian countries employed external regime legitimation strategies but those strategies differ based on regime type. Overall, we see a continuity and persistence in reporting regional cooperation but underreporting of regional conflict throughout the 2016-2017 timeframe of this study.
\end{abstract}

Keywords: external legitimation, media framing, authoritarian regimes, Central Asia Watch Project.

\footnotetext{
${ }^{\mathrm{i}}$ Eurasian Research and Analysis Institute, Central Asia Watch Project, Washington, D.C., USA

${ }^{\text {ii }}$ Department of Geography and Environmental Science, University of Reading, Russell Building, Whiteknights Campus, PO Box 227, Reading RG6 6AB, UK.

iii Schar School of Policy and Government, George Mason University, Arlington, VA, USA.

*Corresponding author
} 


\section{Introduction}

Any regime requires a certain level of legitimacy and support to ensure its long-term security (Isaacs and Frigerio 2019). Thus, regimes apply various strategies to gain support and legitimize their existence. This is particularly important for young countries, such as those in Central Asia, that are looking to establish their identities. External regime legitimation is one of the strategies that help governments to achieve regime stability. This strategy is used to acquire international support, which further supports internal political systems (Schatz 2009; von Soest and Grauvogel 2015). External legitimation may include some or all of the following activities: engaging with world leaders, joining international organizations, inviting nongovernmental participation, offering services as an international mediator, and participating in peace-building activities (Schatz 2009).

In controlled regimes, the dissemination of news stories that focus on positive international aspects of the state's policies and actions can be part of an external legitimation strategy. News agencies can reinforce the regime by promoting news that shows international support for the regime (del Sordi and Dalmasso 2018; Holbig 2011). For example, Holbig shows that the Chinese leadership employs "explicit acts of international recognition" to create a positive image of itself in the national discourse. Mass media thus appears to be relevant to both internal and external regime legitimation strategies, which complement and positively strengthen one another. 
Schatz's (2009) research on regime legitimacy in Central Asia led him to conclude that Kazakhstan has employed the external legitimacy strategy since the early 1990s. Schatz noted that former President of Kazakhstan, Nursultan Nazarbayev, frequently travelled to the West, encouraged establishment of foreign embassies, and proposed peace and security arrangements - all to convey Kazakhstan's integration into and cooperation with international society. Nazarbayev used his international credentials as a peacekeeper to present his regime as a creator of tranquillity over his multiethnic domestic society, thus legitimizing its existence.

Although we know that many states, including Kazakhstan, have used external regime legitimation strategies, the question remains as to what extent these strategies are used by the Central Asian republics today. In this article, we ask the following question: What messages do Central Asian states communicate to external audiences to legitimize their regimes internally? Specifically, we explore this question by examining how state framing of regional relations is relevant to regime legitimation practices.

This article contributes to research that examines authoritarianism and legitimation in Central Asia and illustrates that the main concern of Central Asian rulers is to maintain power (Cummings 2002). The study analysed a news dataset collected by the Central Asia Watch (CAW) Project, ${ }^{1}$ a project that systematically analyses news articles published by the state-run media outlets of Kazakhstan, the Kyrgyz Republic, Tajikistan, Turkmenistan, and Uzbekistan. In our analysis, we demonstrate how Central Asian state-run media outlets applied a cooperative framing to their reporting of regional interactions to legitimize ruling governments. Beyond their scholarly relevance, our findings help citizens, policymakers, and investors who use

\footnotetext{
${ }^{1}$ See https://centralasiawatch.com.
} 
information from state-owned sources to better evaluate the information they receive from and about the region.

\section{Background}

The five countries of Central Asia emerged from the collapse of the Soviet Union in 1991, with borders, economies, and political systems that would seem to provide the basis for conflict rather than cooperation. The delicate resource-sharing model exercised during the Soviet period between the energy-rich but water-poor nations (Kazakhstan, Turkmenistan, Uzbekistan) and the water-rich but energy-poor nations (Kyrgyz Republic, Tajikistan) broke down quickly, and the struggle to reach new agreements has been a dominant regional issue (Elhance 1997; Krutov and Spoor 2003; Bichsel 2009; Sakeeva 2013; Pak and Wegerich 2014; Rumer 2002; Menga 2018). Scholars such as Nick Megoran (2017) have argued, however, that the primary driver of regional conflict is a flowering of nationalism.

Since independence, the narrative of Central Asia that most Western observers have articulated in literature and thought pieces is what Heathershaw and Megoran (2011) have characterized as a 'discourse of danger,' grouped into the lenses of 'obscure, oriental, and fractious.' Obscure in this context refers to the conception of Central Asia as a region left behind by the world economy and international politics, with analysts highlighting the inadequacy of government policies in stimulating growth (Kaminski and Mitra 2010). Oriental highlights the idea of an unknowable region that is beset with religious radicalism and opaque decision-making. Fractious means that the region is locked into intractable violence as a result of a legacy of 
Soviet state-building and ethnic diversity in the region (Devlet 1997), explaining the cause of periodic ethnic conflicts.

Disappointingly, the world still tends to view the region as an analytical black box, regardless of the considerable differences among the five countries. Central Asia is generally perceived as an 'authoritarian region,' but not all forms of authoritarian control are the same (Koch 2013; Menga 2019). As Schatz (2009) noted, for example, Kazakhstan and the Kyrgyz Republic featured a softer form of authoritarianism compared to some of the other regimes at the time. In this regard, von Soest and Grauvogel (2015) outlined how the Central Asian states draw on different legitimation strategies that may emphasize some of all of the following: their foundational myth, the glorification of their president, their engagement with the international community, and their socioeconomic performance.

The Western conflict narrative of bitterly adversarial foreign policy relations in Central Asia has begun to transform over the last couple of years, replaced by a new narrative of flowering diplomatic rapprochement and regional cooperation. Much of this transformation is linked to the foreign policy rhetoric of Uzbek president Shavkat Mirziyoyev, who has made a number of public statements since coming to power in late 2016 attesting to the importance of creating good relationships with Uzbekistan's neighbours. Tellingly, the language used here, such as 'Reset' (Hashimova 2018) or 'Spring' (Cornell and Starr 2018) in news article titles implies a complete departure from an older medium toward a more positive atmosphere. 
Relaxed visa regimes and trade agreements among the states have boosted the perception of Central Asian cooperation and regional integration, a result generally heralded as potentially leading to major geopolitical developments for Eurasia (Horak 2018), a stronger defence in the larger battle with religious radicalization (Gavrilis 2017), and a tourism boom and economic

growth throughout the region (Asian Development Bank 2019). While many publications make sure to include caveats when promoting this narrative, they are increasingly depicting a Central Asia that is poised to integrate economically while also embracing diplomatic engagement and becoming an important political bloc in Eurasia. Thus, it is evident that the media plays a crucial role in shaping our perception of a particular region, an issue that will be discussed in greater detail below.

\section{External Regime Legitimation and Media Framing}

All regimes, irrespective of whether they trend democratic or authoritarian, need to have a certain level of legitimacy to ensure their longevity (Isaacs and Frigerio 2019). Thus, regimes apply various strategies to gain support and legitimize their existence, including ideology, charisma, elections, performance, international engagement, external legitimation, and other legitimacy claims (Burnell 2006; von Soest and Grauvogel 2015). These strategies are highly interlinked and may coexist. In fact, Grauvogel and von Soest (2014) argue that regimes must apply a variety of legitimation strategies in order to build a stronger legitimation case.

Burnell (2006) defines external legitimation strategy as gaining international recognition and support (material or symbolic) from other states in order to manufacture legitimacy at home. To 
bolster its external and internal legitimacy, a regime can engage internationally by conducting state visits, opening up embassies, joining international organizations, volunteering to facilitate peace and security negotiations, and promoting cooperation among states in general (Schatz 2009). Governments use various communication tools, particularly media outlets, to publicize their external legitimation efforts to gain support for their regimes (Allison 2006; Gross and Kenny 2008; Anceschi 2011; Rollberg and Laruelle 2015).

Media is a regime-legitimizing tool because it 'frames,' or assembles, narratives to promote a chosen interpretation of an event (Entman 2007). Thus, journalists use framing to play an important role in constructing the news: the choices they make about 'language, quotations, and relevant information lead to emphasis upon certain features of a news story' (Shah et al. 2002). Moreover, news frames that emphasize positive or negative aspects of an issue influence public support for specific policies (Price et al. 1997; de Vreese and Boomgaarden 2003). No matter how hard journalists try to present unbiased news, framing is inescapable. All journalists must necessarily frame their stories before sharing them with the public.

Academics classify frames into two main groups: substantive and procedural (Entman 2004). Substantive frames perform at least two of the following basic functions in covering political events, issues, and actors: defining effects or conditions as problematic, identifying causes, conveying a moral judgment, and endorsing remedies or improvements. Procedural frames have a narrower focus and function. They suggest evaluations of political actors' legitimacies based on their techniques, successes, and representativeness. Callaghan and Schnell (2005) classify frames into two main groups: while their typology of frames is similar to Entman's, they 
distinguish between issue-specific and generic frames. They further divide issue-specific frames into thematic and episodic: thematic frames place political issues or events in a certain context, while episodic frames focus on specific events or persons. Generic frames, on the other hand, describe concepts in a broad way and can act as broader frames for specific policy issues.

\section{Methods and Limitations}

This study used a quantitative content analysis method to examine how a Central Asian government-owned news agency, the state's tool to promote its legitimation, employs the external regime legitimation strategy while reporting on regional interactions. The unit of analysis is the individual online news article. The data was collected by our research team through the Central Asia Watch (CAW) Project, which tracks economic, social, and political developments in Central Asia via their interstate conflict and cooperation news database. For this study, we analysed data for the period from January 2016 to December 2017.

To examine the reporting approaches by these five states, we selected one state-run news outlet from each country. We also examined one Western media outlet to receive a more unbiased media perspective for comparison. The six news outlets that we examined were: the national news agency of Kazakhstan-Kazinform; the official news agency of the Kyrgyz RepublicKabar; the national information agency of Tajikistan-Khovar; an electronic newspaper agency of the State News Agency of Turkmenistan-Turkmenistan Golden Age (TGA); Uzbekistan National News Agency—UzA; and the United States government-funded Radio Free Europe/Radio Liberty (RFE/RL). 
Since this study explores external legitimation with a regional focus, we define regional news articles as those pertaining to bilateral or multilateral events that occurred between two or more Central Asian states. To identify regional news articles for analysis, we conducted a two-step article selection process (see Appendix). First, a computer-based program conducted a content analysis of all the English-language articles produced by the six news outlets between January 2016 and December 2017 and selected articles that mentioned 'Kazakh,' 'Kyrgyz,' 'Tajik,' 'Turkmen,' and 'Uzbek.' These articles were automatically coded by computer as regional news stories. For each article selected, the computerized program also recorded the news agency name, title, publication date, and the weblink to the original article. In the second step, human coders reviewed and verified the regional articles coded by computer and corrected false positives that failed to meet the above definition of a regional news article.

Once verified, the regional articles were coded for type of generic frames, as identified by Callaghan and Schnell (2005). Coding for type of generic frames allowed us to focus on broad policy issues, specifically international (regional) conflict and cooperation, for example, answering the question whether the states promote a positive image of themselves at the regional level. We identified the generic frame of conflict according to Semetko and Valkenburg (2000): a frame that 'emphasizes conflict between individuals, groups, or institutions as a means of capturing audience interest.' We used the definition of conflict to help define the cooperation frame: a frame that emphasizes cooperation between individuals, groups, or institutions as a means of capturing audience interest. 
The frames of regional news articles were coded using the Conflict Cooperation Scale (CCS). ${ }^{2}$ The CCS was developed by the CAW Project and is based on the Transboundary Freshwater Dispute Database (TFDD) scale (Wolf 1999). The CCS provides a rubric for coders to classify news articles as having either a conflict frame (negative score), cooperation frame (positive score), or neutral if neither applies (0 score). To better measure the level of conflict and cooperation reported, the CCS distinguishes between verbal and action events, given that action events generally correspond with a higher level of cooperation or conflict. The CCS assigns a value of \pm 1 to verbal events and a value of \pm 2 to action events. Articles that summarized weekly events, delivered monthly reports, or produced other types of reviews are coded as 99. Intercoder reliability, when two coders independently analysed a subset of the same 100 news articles, was found to be 93 percent. In general, coder agreement of 90 percent or greater is considered highly reliable (Lavrakas 2008).

To track where the reported conflict and cooperation were occurring, bilateral events were noted. To track the bilateral events, we coded articles for dyads, or two-country pairs, which were associated with the conflict frame (negative CCS) or cooperation action frame (CCS of +2). During the dyad analysis, articles featuring three or more countries were recorded as 'two plus' and were not included in the analysis due to the ambiguity of whether they were covering a multilateral event or multiple bilateral events. Articles with a CCS of 0 or 99 were omitted for lack of relevance. Given their greater consequence, only articles coded as cooperative action events (+2) were analysed for dyads.

\footnotetext{
${ }^{2}$ Read more about the Conflict Cooperation Scale in the Appendix.
} 
Additionally, articles with CCS values of $-1,-2$, and +2 were coded for topics or sectors in which regional cooperation and conflict were reported. The sectors identified for this research were border, culture, disaster aid, elections, energy, military, terrorism, trade, transportation, sport, water, presidential state visit, multisector, and other. For sector coding, we used an inductive approach in which we analysed articles with an open view and with a goal to revealing the array of possible sectors. Articles with CCS values of +1 were omitted from sector coding due to their high volume and being less consequential than the +2 articles.

This study has data-related limitations. We are not questioning the authenticity of the information provided by the news outlets examined, but we acknowledge that the articles produced are most likely to have a particular bias and limitation in scope. This bias can be partially examined though comparative data analysis, but due to the small sample size of the news agencies examined — one agency per Central Asian country and one out-of-region media outlet - we cannot make statements regarding the degree of this limitation. We also could not collect and examine 2016 news articles published by the Kyrgyz state-run media outlet, Kabar. During our data extraction process in 2017, we discovered that articles published in 2016 had been archived and removed from the Kabar website and were not available at the time of collection.

It is also important to note that we examined only articles published in the English language. Clearly, English-language articles are meant for a different target audience than regional readers consuming information in their national languages or in Russian. We note that overall, there is a difference in quantitative and thematic coverage between English and non-English publications, 
but it is beyond the scope of this research to compare and contrast coverage in different languages.

\section{Results}

A total of 38,614 articles were processed and coded by the automated system. The largest number of articles came from Kazinform $(\mathrm{n}=25,963)$, followed by 3,375 articles from TGA, 2,873 from Kabar (data only for 2017), ${ }^{3} 2,576$ from UzA, 2,099 from Khovar, and 1,728 from RFE/RL. The computerized system analysed all 38,614 articles and coded them as regional in cases when content analysis showed that the text of an article contained names of at least two Central Asian states. Human coders reviewed all the articles coded as regional and verified 2,488 of these articles as regional. Kazinform contributed the most regional articles (36 percent), followed by 21 percent from Kabar, 19 percent from TGA, 11 percent from UzA, 8 percent from Khovar, and 6 percent from RFE/RL (Table 1).

\footnotetext{
${ }^{3}$ The 2016 Kabar articles were not available at the time of data collection and analysis.
} 
Table 1. Regional articles sorted by CCS rating and news resource for articles published between 2016 and 2017

\begin{tabular}{|c|c|c|c|c|c|c|c|}
\hline \multirow[b]{2}{*}{ Resource } & \multicolumn{2}{|c|}{ Conflict } & \multirow{2}{*}{$\begin{array}{c}\text { Neutral } \\
0 \\
\end{array}$} & \multicolumn{2}{|c|}{ Cooperation } & \multirow{2}{*}{$\begin{array}{c}\text { N/A } \\
99 \\
\end{array}$} & \multirow[b]{2}{*}{ Total } \\
\hline & -2 & -1 & & +1 & +2 & & \\
\hline KABAR & 8 & 13 & 20 & 341 & 135 & 2 & 519 \\
\hline 2017 & 8 & 13 & 20 & 341 & 135 & 2 & 519 \\
\hline KAZINFO & 15 & 21 & 66 & 582 & 195 & 7 & 886 \\
\hline 2016 & 9 & 10 & 33 & 299 & 83 & 6 & 440 \\
\hline 2017 & 6 & 11 & 33 & 283 & 112 & 1 & 446 \\
\hline KHOVAR & - & 1 & 19 & 153 & 28 & - & 201 \\
\hline 2016 & - & - & 9 & 70 & 11 & - & 90 \\
\hline 2017 & - & 1 & 10 & 83 & 17 & - & 111 \\
\hline TGA & - & - & 19 & 308 & 140 & 1 & 468 \\
\hline 2016 & - & - & 9 & 120 & 51 & 1 & 181 \\
\hline 2017 & - & - & 10 & 188 & 89 & - & 287 \\
\hline UZA & - & - & 12 & 156 & 102 & - & 270 \\
\hline 2016 & - & - & 11 & 58 & 19 & - & 88 \\
\hline 2017 & - & - & 1 & 98 & 83 & - & 182 \\
\hline RFE/RL & 21 & 23 & 11 & 57 & 31 & 1 & 144 \\
\hline 2016 & 12 & 3 & 4 & 20 & 9 & - & 48 \\
\hline 2017 & 9 & 20 & 7 & 37 & 22 & 1 & 96 \\
\hline Total & 44 & 58 & 147 & 1,597 & 631 & 11 & 2,488 \\
\hline
\end{tabular}

\section{Changing trends between 2016 and 2017}

We examined framing by news agency and year. First, we looked at whether there was a change in reporting on international relations in the region between 2016 and 2017. The data shows that the number of news stories reported through the cooperation frame $(\mathrm{CCS}+1$ and +2$)$ increased from 2016 to 2017 in four outlets: UzA had a 135 percent increase, followed by a 103 percent increase in RFE/RL, 62 percent in TGA, and 23 percent in Khovar. We did not observe a 
noticeable change in Kazinform's reporting, which saw only a 3 percent increase. Overall, very few stories were reported through the conflict frame (CCS -1 and -2). TGA and UzA did not report any conflict stories at all. Khovar reported only one negative event. Kazinform, RFE/RL, and Kabar were the only agencies that reported regional events through the conflict frame. Because 2016 data for Kabar was not available, an annual change in reporting negative regional events could be observed only for Kazinform and RFE/RL. Kazinform showed little difference in its conflict reporting, producing two fewer articles in 2017 compared to 2016. RFE/RL, on the other hand, had a 93 percent increase in conflict reporting.

\section{News reported through conflict frames}

The number of regional news stories reported through a conflict frame was 102 (Table 2), 4 percent of the regional articles' subset. The dyad analysis, which indicates the two countries on which a bilateral article focuses, showed that 41 percent of conflict news stories reported in 2016 and 81 percent in 2017 (74 percent when excluding Kabar $^{4}$ ) were between Kazakhstan and the Kyrgyz Republic. Other notable conflict dyads included Kazakhstan-Turkmenistan and Uzbekistan-Kyrgyz Republic, which accounted for a combined 41 percent of the conflict reporting in 2016 but had minimal mentions in 2017.

\footnotetext{
${ }^{4}$ Because Kabar articles were not included in the 2016 analysis, a more accurate indicator of the change in reporting of this conflict dyad requires omitting Kabar articles in 2017.
} 
Table 2. Conflict frame articles (CCS -1 and -2) by news resource

\begin{tabular}{|c|c|c|c|c|c|c|c|c|c|c|c|c|c|c|}
\hline \multirow[b]{3}{*}{ Conflict Dyad } & \multicolumn{4}{|c|}{2016} & \multirow{3}{*}{2016 Total } & \multicolumn{7}{|c|}{2017} & \multirow{3}{*}{2017 Total } & \multirow{3}{*}{ Grand Total } \\
\hline & \multicolumn{2}{|c|}{$\begin{array}{l}\text { KAZINFORM } \\
\text { CCS }\end{array}$} & \multicolumn{2}{|c|}{$\begin{array}{c}\mathbf{R F E} / \mathbf{R L} \\
\text { CCS }\end{array}$} & & \multicolumn{2}{|c|}{$\begin{array}{c}\text { KABAR } \\
\text { CCS }\end{array}$} & \multicolumn{2}{|c|}{$\begin{array}{l}\text { KAZINFORM } \\
\text { CCS }\end{array}$} & \multirow{2}{*}{\begin{tabular}{|c} 
KHOVAR \\
CCS \\
-1 \\
\end{tabular}} & \multicolumn{2}{|c|}{$\begin{array}{c}\text { RFE/RL } \\
\text { CCS }\end{array}$} & & \\
\hline & -2 & -1 & -2 & -1 & & -2 & -1 & -2 & -1 & & -2 & -1 & & \\
\hline Kazakh-Kyrgyz & 6 & 6 & 2 & - & 14 & 8 & 12 & 4 & 11 & - & 5 & 15 & 55 & 69 \\
\hline Kazakh-Turkmen & 3 & - & 4 & - & 7 & - & - & - & - & - & 1 & - & 1 & 8 \\
\hline Kazakh-Uzbek & - & 1 & - & - & 1 & - & - & - & - & - & - & - & - & 1 \\
\hline Tajik-Turkmen & - & - & - & - & - & - & - & - & - & 1 & - & 2 & 3 & 3 \\
\hline Tajik-Uzbek & - & - & 1 & 1 & 2 & - & - & - & - & - & 2 & - & 2 & 4 \\
\hline Uzbek-Kyrgyz & - & 1 & 5 & 1 & 7 & - & - & - & - & - & - & 2 & 2 & 9 \\
\hline Uzbek-Turkmen & - & - & - & - & - & - & - & - & - & - & 1 & - & 1 & 1 \\
\hline Two plus & - & 2 & - & 1 & 3 & - & 1 & 2 & - & - & - & 1 & 4 & 7 \\
\hline CCS -2 Total & 9 & & 12 & & 21 & 8 & & 6 & & & 9 & & 23 & 44 \\
\hline CCS -1 Total & & 10 & & 3 & 13 & & 13 & & 11 & 1 & & 20 & 45 & 58 \\
\hline Grand Total & & & & & 34 & & & & & 1 & & & 68 & 102 \\
\hline
\end{tabular}

We used an inductive approach to examine the conflict-framed articles for sectors. Ten sectors had conflicts reported: border, elections, culture, energy, sport, terrorism, trade, transportation, water, and other (miscellaneous). The Kazakhstan-Kyrgyz Republic conflict dyad received the most regional news coverage; the conflict incidents between these two countries covered seven sectors. The most conflictive sector between these two countries was border (Figure 1), with fifty articles published between 2016 and 2017. The border sector was also noted as a common area of reported conflict for all Central Asian states. The second most conflictive sector was elections, which had seventeen conflict articles published 2017 (none in 2016). All electionrelated conflicts occurred between Kazakhstan and the Kyrgyz Republic. The water and energy sectors had some of the least conflict reporting in our sample: Only four articles, three energy and one water, were published, all from 2016. Out of three conflict-framed energy stories reported by Kazinform, two occurred between the Kyrgyz Republic and Kazakhstan and one between more than two countries. The only water conflict story was reported by RFE/RL in 2016 and involved Tajikistan and Uzbekistan. 
We noticed that although the media agencies of Uzbekistan, Turkmenistan, and Tajikistan (with the exception of one article on sport) were not found to publish articles framed through the conflict frame, other news outlets did report conflict incidents that involved Tajikistan, Turkmenistan, and Uzbekistan. In total, there were twenty-six conflict stories (thirty-three stories when counting 'two plus' articles) produced by Khovar (one), Kazinform (five), and RFE/RL (twenty) that involved Tajikistan, Turkmenistan, and Uzbekistan: eighteen stories on border, six on transportation, one on water, and one on sport.

Figure 1. Sankey diagram of sectoral issues by conflict dyad (2016-2017)

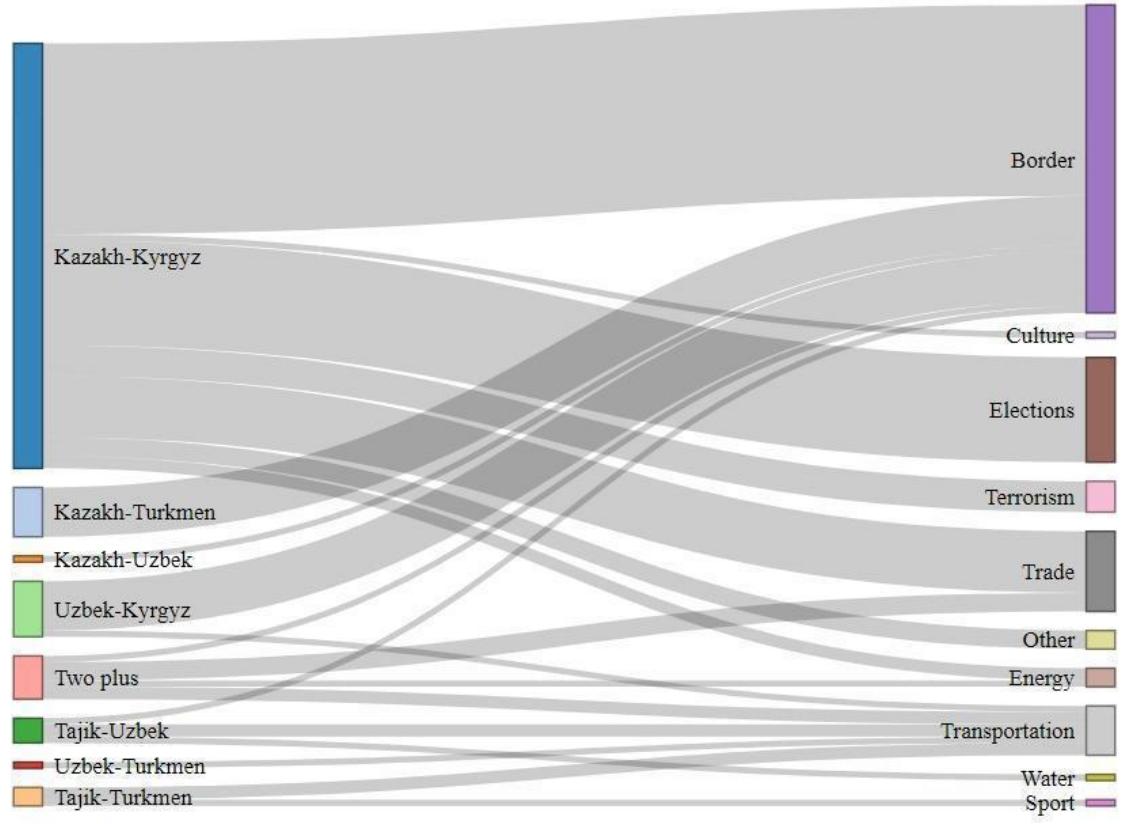


To better understand the media outlets' approach to reporting, we also examined which countries the agencies were reporting on. When the Kyrgyz Republic and Kazakhstan published on their bilateral issues, no other Central Asian agency covered those issues. Kabar and Kazinform were the only agencies that regularly reported conflict incidents involving their own countries, but they also rarely reported a conflict that did not involve their own country. For example, conflicts between the Kyrgyz Republic and Uzbekistan were largely not reported by regional media, with one exception by Kazinform. Additionally, RFE/RL, as an international outlet, reported on conflict dyads and sectors absent from Central Asian outlets.

\section{News reported through cooperation frames}

After looking at conflict reporting, we examined the news articles reported via the cooperation frame. Out of the 2,488 regional articles, 631 were coded as pertaining to a cooperative action and 1,597 to cooperative verbal events. All media outlets tracked had an increase in reporting regional cooperation in 2017 over 2016. We used an inductive approach to examine the 631 cooperative action news stories and identified twelve sectors: border, culture, disaster aid, elections, energy, military, trade, transportation, water, multisector, other, and presidential state visits. The volume of stories solely focused on presidential state visits, and the importance of such events necessitated that they be tracked as their own sector category. When comparing reported cooperative actions in 2016 and $2017,{ }^{5}$ several sectors more than doubled in cooperative actions: border, culture, presidential visits, and multisector actions (Table 3). UzA saw the greatest increase in reporting of presidential state visits from 2016 to 2017.

\footnotetext{
${ }^{5}$ Omitting Kabar data due to the lack of comparable data for 2016.
} 
Table 3. Cooperative actions by resource and sector

\begin{tabular}{|c|c|c|c|c|c|c|c|c|c|c|c|c|c|}
\hline \multirow[b]{2}{*}{ Resource } & \multicolumn{12}{|c|}{ Cooperative Action Sector } & \multirow[b]{2}{*}{ Total } \\
\hline & Border & Culture & Disaster & Elections & Energy & Military & Trade & Transportation & Water & Multisector & Other & Presidental Visit & \\
\hline 2016 & 6 & 2 & 1 & 5 & 6 & 19 & 61 & 23 & 1 & 15 & 14 & 20 & 173 \\
\hline TGA & - & - & - & - & - & - & 33 & 11 & - & 4 & 1 & 2 & 51 \\
\hline KAZINFORM & 3 & 2 & 1 & 3 & 2 & 18 & 22 & 11 & 1 & 7 & 7 & 6 & 83 \\
\hline KHOVAR & - & - & - & 1 & 3 & - & 1 & 1 & - & 1 & 2 & 2 & 11 \\
\hline UZA & - & - & - & 1 & - & - & 5 & - & - & 2 & 4 & 7 & 19 \\
\hline $\mathrm{RFE} / \mathrm{RL}$ & 3 & - & - & - & 1 & 1 & - & - & - & 1 & - & 3 & 9 \\
\hline 2017 & 40 & 17 & 3 & 3 & 14 & 19 & 75 & 37 & 1 & 104 & 40 & 105 & 458 \\
\hline $2017^{*}$ & 24 & 8 & 1 & 3 & 8 & 15 & 48 & 30 & 1 & 83 & 23 & 79 & 323 \\
\hline TGA & 1 & 3 & - & 2 & 3 & - & 21 & 15 & 1 & 21 & 3 & 19 & 89 \\
\hline KABAR* & 16 & 9 & 2 & - & 6 & 4 & 27 & 7 & - & 21 & 17 & 26 & 135 \\
\hline KAZINFORM & 14 & 5 & - & 1 & 3 & 14 & 21 & 9 & - & 22 & 9 & 14 & 112 \\
\hline KHOVAR & 1 & - & - & - & - & - & 1 & 2 & - & 7 & 4 & 2 & 17 \\
\hline UZA & 3 & - & 1 & - & 1 & 1 & 4 & 1 & - & 26 & 6 & 40 & 83 \\
\hline $\mathrm{RFE} / \mathrm{RL}$ & 5 & - & - & - & 1 & - & 1 & 3 & - & 7 & 1 & 4 & 22 \\
\hline Total* & 30 & 10 & 2 & 8 & 14 & 34 & 109 & 53 & 2 & 98 & 37 & 99 & 496 \\
\hline Total & 46 & 19 & 4 & 8 & 20 & 38 & 136 & 60 & 2 & 119 & 54 & 125 & 631 \\
\hline
\end{tabular}

*Denotes removal of the Kabar data to provide a more accurate indicator of the change in reporting of cooperative actions by sector.

As with conflict frames, most media outlets tended not to report on cooperative action events between other states in the region; when cooperation occurred between two Central Asian states, it was usually reflected in the media outlets of only the two countries involved in the cooperative action (Table 4). Of the Central Asian news agencies tracked, Kabar showed the greatest tendency to post on cooperation between other countries in Central Asia, posting stories on eight out of a possible ten cooperative action dyads. We observed that these stories tended to be reposting of other news agencies' reporting. 
Table 4. Cooperative action dyads reported by resource

\begin{tabular}{|c|c|c|c|c|c|c|c|c|c|c|c|c|c|c|c|c|}
\hline \multirow[b]{2}{*}{ Cooperative Dyad } & \multirow{2}{*}{\multicolumn{2}{|c|}{$\begin{array}{r}2016 \\
\text { KAZINFORM KHOVAR }\end{array}$}} & & \multirow[b]{2}{*}{2016 Total } & \multirow{2}{*}{\multicolumn{3}{|c|}{2017}} & \multirow{2}{*}{ RTGA } & \multirow[b]{2}{*}{ UZA } & \multirow[b]{2}{*}{ RFE/RL } & \multirow[b]{2}{*}{2017 Total } & \multirow[b]{2}{*}{ Total } & \multicolumn{2}{|c|}{ Adjusted* } \\
\hline & & & TGA & UZA & $\mathrm{RFE} / \mathrm{RL}$ & & & & & & & & & & 2017 Total & Total \\
\hline Kazahk-Tajik & 7 & 1 & - & - & - & 8 & 2 & 5 & 1 & - & - & 1 & 9 & 17 & 7 & 15 \\
\hline Kazakh-Kyrgyz & 21 & - & - & - & - & 21 & 40 & 34 & - & - & 4 & 4 & 82 & 103 & 42 & 63 \\
\hline Kazakh-Turkmen & 11 & - & 4 & - & - & 15 & 2 & 11 & - & 26 & - & 1 & 40 & 55 & 38 & 53 \\
\hline Kazakh-Uzbek & 14 & - & - & 7 & 2 & 23 & 3 & 36 & - & - & 28 & 1 & 68 & 91 & 65 & 88 \\
\hline Kyrgyz-Turkmen & - & - & 16 & - & - & 16 & 1 & - & - & 9 & - & - & 10 & 26 & 9 & 25 \\
\hline Tajik-Kyrgyz & 1 & 3 & - & - & 1 & 5 & - & - & 1 & - & - & - & 1 & 6 & 1 & 6 \\
\hline Tajik-Turkmen & - & - & 9 & - & - & 9 & - & - & 2 & 19 & - & - & 21 & 30 & 21 & 30 \\
\hline Tajik-Uzbek & - & 5 & - & 2 & - & 7 & 2 & 1 & 5 & - & 3 & 2 & 13 & 20 & 11 & 18 \\
\hline Uzbek-Kyrgyz & - & - & - & 1 & 4 & 5 & 55 & - & - & - & 31 & 4 & 90 & 95 & 35 & 40 \\
\hline Uzbek-Turkmen & - & - & 1 & 2 & - & 3 & 2 & - & - & 28 & 12 & 4 & 46 & 49 & 44 & 47 \\
\hline Two plus & 29 & 2 & 21 & 7 & 2 & 61 & 28 & 25 & 8 & 7 & 5 & 5 & 78 & 139 & 50 & 111 \\
\hline Total & 83 & 11 & 51 & 19 & 9 & 173 & 135 & 112 & 17 & 89 & 83 & 22 & 458 & 631 & 323 & 496 \\
\hline
\end{tabular}

*Denotes removal of the Kabar data to provide a more accurate indicator of the change in reporting of cooperative actions by sector.

\section{Discussion}

\section{External legitimation media approach}

The analysis of state-run Central Asian media outlets showed that all Central Asian republics employ external regime legitimation strategies. News articles reporting regional relations through the frame of conflict made up less than 1 percent of the total content of the outlets that published them. Despite the general discourse that before 2017 (until Karimov's presidency in Uzbekistan) the region was more conflictive, our data showed persistence of cooperation frame reporting throughout the 2016 and 2017 periods. This indicates that these Central Asian staterun media outlets have likely been using the external legitimation approach in news reporting for a longer period of time. Rather than leading to a change in legitimation approach, the recent developments in Central Asia appear to have expanded the use of existing strategies. 
We noticed that the application of the external legitimation approach differed from one agency to another. For example, Khovar, TGA, and UzA produced only cooperative regional stories, showing no indication of disagreement between regional neighbours, while Kabar and Kazinform produced some conflict stories. The difference of Kabar's and Kazinform's journalism could be explained in part by Gross and Kenny's (2008) reporting that journalism schools in Kazakhstan and the Kyrgyz Republic are modern, have US-style curricula, and host Western or Western-educated faculties, so they may be producing journalists who are more open to reporting through different frames or challenging established norms. Schatz (2009), however, can explain this difference by the difference in type of regime: Kazakhstan and the Kyrgyz Republic have soft authoritarian regimes. Lastly, groups like Freedom House, an American nongovernmental organization that conducts research on democracy, political freedom, and human rights, show a strong correlation between freedom of the media and freedom in general. Freedom House ranks Kazakhstan and the Kyrgyz Republic as freer than their neighbours (Freedom House 2017).

\section{Excessive reporting of cooperation}

Many media sources attribute the recent increase in regional cooperation to the new president in Uzbekistan (Nourzhanov 2018; Sorbello 2018). Our data confirm this, as Shavkat Mirziyoyev indeed appears to contribute to increased reporting in regional cooperation: UzA, along with other media outlets, reported numerous state visits and agreement-signing events involving Uzbekistan during 2017. Presidential state visit news articles stood out during the analysis 
because the number of articles on presidential visits almost tripled in 2017; most of these articles were reported by UzA.

Although many of these articles did cover important aspects of diplomatic engagements, there were many articles that did not have substantial informational value: Separate articles reported that the president left to a neighbouring country, was in flight, and arrived at the destination. Such intensive reporting on presidential visits shows that UzA is making significant efforts in portraying Uzbekistan as a willingly cooperative state; this is in line with the general tendency underpinning personalist-authoritarian regimes in Central Asia (Isaacs 2019). It appears that Uzbekistan, like Kazakhstan in the early 1990s, is looking to derive its legitimacy from external recognition, while broadcasting international support inward to domestic audiences.

It is worth stating that the new presidency in Uzbekistan did not appear to change the reporting strategies within UzA. The agency still does not report conflict incidents involving Uzbekistan even though they occur and are reported by other media outlets. Since we are examining change in media reporting within one year of Mirziyoyev's presidency, lack of changes may be due to the institutional resistance to change (Roland 2004). However, Mazepus et al. (2016) argues that although the regimes may change their ideological positions, their legitimization strategiessuch as external legitimization — are often robust and therefore remain relatively static over time.

\section{Underreporting conflict}


The reporting of conflict stories in the five national media outlets was minimal, particularly when compared to the RFE/RL. Thus, it appears that the Central Asian state-run media outlets examined in our study implement the external legitimation strategy by minimizing their reporting on regional disagreements. This approach to news writing is explained as providing regime security by Jourde (2007). He argues that controlled regimes recognize the role of stability in Western governments' world views and use a representation of such stability to help them against international and domestic democratization pressures.

We found that of the state-run media outlets examined, only those of Kazakhstan and the Kyrgyz Republic made an effort to report conflict incidents, mostly focusing on these two countries. That explains why in this study Kazakhstan and the Kyrgyz Republic appear the most in conflict articles. Overall, in striving to portray a stable and conflict-free region, all the media outlets minimized reporting of regional conflict events.

UzA did not report any conflict news stories from 2016 to 2017. A review of the border sector, for example, revealed that there were issues at the border during that timeframe. An article published by UzA in 2017 through the cooperation frame states that 'it was somewhat difficult' for people on either side of the Kyrgyz-Uzbek border to cross into the adjoining country. The reporter referred to the 'solving of this problem' as 'a historic event' toward cooperation between the Uzbek and Kyrgyz people — all indicating that a border issue between the neighbours existed and was significant. In addition, many meetings held in 2017 between the working groups of the Kyrgyz Republic, Tajikistan, and Uzbekistan on their border issues allow 
us to conclude that although border disagreements were barely reported during the study period, these conflicts existed in the region and were a priority to resolve.

The apparent underreporting of the border issues allows us to hypothesize that other sectors reported as problematic by Kazinform and RFE/RL, but not reported as such by other agencies, are likely to have transboundary issues as well. Freedman (2014), who studies obstacles to covering transboundary issues in the region, attributes conflict underreporting (such as we observed in our study) to the avoidance of controversy, self-censorship, lack of access to information, limited transboundary collaboration, inadequate professional skills, and weakened minority-language media.

Of note is that there was an absence of reporting on regional conflict between upstream and downstream states over energy and water resources: No water or energy conflict stories were reported in 2017, and only four stories were reported in 2016. Kazinform reported three news stories on energy: two of them covered the same Kazakh-Kyrgyz event, and one of them focused on a multilateral energy issue. RFE/RL produced one article on water conflict between Tajikistan and Uzbekistan. The news agencies of Tajikistan, Turkmenistan, and Uzbekistan reported no negative incidents over energy or water resources. Based on our literature review, however, academia perceives water and energy issues as highly conflictive, similar to what we saw with border issues. Unlike border reporting in the media, there was a near total absence of water-related articles, indicating a lack of cooperative events to report on for this sector. In keeping with the regime legitimation approach, news agencies appear to have ignored sectors 
where transboundary issues remain in order to project a greater sense of cooperation and stability.

\section{Employing media framing to achieve additional objectives}

Aware of possible conflict underreporting by TGA, Khovar, and UzA, we analysed the conflict stories reported by Kabar and Kazinform. Both agencies, while applying the external regime legitimation strategy, decided to report on conflicts in the following sectors: borders, elections, energy, terrorism, and trade. Border issues in 2016 differed from the border issues in 2017 by triggers, causes, and dyads. Border conflict articles dominated the conflict frame reporting in 2016, accounting for eighteen out of thirty-four conflict articles. Those 2016 border conflict stories primarily covered Kazakh-Turkmen and Kyrgyz-Uzbek incidents that were triggered by border closures and border demarcation issues, respectively. In 2017, most of the conflict border stories focused on the Kazakh-Kyrgyz border crossing. The reported border conflict arose from Kazakh-Kyrgyz elections conflict — the second most commonly reported conflictive sector in 2017.

The 2017 Kazakh-Kyrgyz spat showed a brief departure from their media framing approaches that were otherwise consistent. This dispute started with the Kyrgyz Republic accusing Kazakhstan of interfering in its elections when the Kazakh president met with a Kyrgyz presidential candidate who later lost the election; the dispute later escalated to Kazakhstan closing border crossings with the Kyrgyz Republic. This conflict, and the strategies the countries implemented to report it, reveals the Kazakh and Kyrgyz power dynamic. In this 
incident (where Kazakhstan has an economic advantage), Kabar maintained coverage of the issue with conflict framing from the start to when the conflict escalated to the international level—with complaints issued to the World Trade Organization (WTO) and Eurasian Economic Union (EAEU) platforms. Kazinform had initially reported on the conflict in response to articles published in Kyrgyz media but stopped once the conflict had the attention of the WTO and EAEU.

Steven Livingston, professor of media and public affairs at George Washington University, explains such reporting as the preference by stronger states to 'privatize' the conflict to limit attention to it, and the desire by more vulnerable states to 'socialize' the incident to find allies against the stronger power (Bajraktari and Parajon 2007). The Kyrgyz republic interpreted Kazakhstan's actions as having a delegitimizing effect on its regime and felt compelled to act. Given the Kyrgyz Republic's weaker position, it socialized the issue by reporting the issue through the conflict frame. Once the conflict was in Kyrgyz media, Kazakhstan likely felt obligated to defend itself through its own media by reporting on, but downplaying, the conflict through its media, while simultaneously taking punitive actions (i.e., closing border crossings) in apparent retaliation. Once the story had enough international attention, Kazakhstan backed off, reopened the border, and both agencies resumed their normal reporting practices. While most conflicts appear to go underreported, this instance shows that certain provocations will result in a change in reporting frames in the Kyrgyz Republic and Kazakhstan.

\section{Minding their own business}


Among the agencies that reported regional conflict (the Kazakh and Kyrgyz news agencies), it was noted that they reported only stories involving their countrys' bilateral relationships. In the dataset examined, only one regional conflict-framed article was identified that did not involve the nation of the news agency publishing the article: a Kazinform article that reported an incident between Uzbekistan and the Kyrgyz Republic.

It was noted that Tajikistan was not involved in or mentioned in many cooperative (CCS equal +2 ) or conflict (CCS equal -1 and -2) news stories. This may be related to the capacity of the Tajik media outlet: Khovar produced the smallest number of regional articles during 2016 and 2017 compared to the other regional outlets. It also may be related to the level of actual cooperation between Tajikistan and other states in the region. The Kyrgyz Republic, which borders Tajikistan, contributed only four cooperative action stories on Tajikistan, focusing on Kazakh-Tajik and Tajik-Uzbek interactions. Additionally, Kabar did not post articles on the Tajik-Kyrgyz cooperation, while Khovar did. Based on these results, it appears that use of external legitimation strategy has a smaller role in Tajikistan's regime legitimation approaches compared to the other nations in Central Asia.

\section{Conclusion}

The analysis of Central Asian state-run media outlets shows that the government media outlets applied the external legitimation approach in reporting regional interactions to depict a region where the nations are in harmony with one another. The manner of applying the external legitimation approach, however, differed from country to country: Kabar and Kazinform, news 
agencies located in the two freest countries in this group of five, reported some regional conflict stories; TGA, Khovar, and UzA did not report on regional conflict at all. The spatial difference in application of external regime legitimation strategy is explained by the difference in the regime type and level of freedom: Kazakhstan and the Kyrgyz Republic have higher freedom rankings and soft authoritarian regimes, thus giving their news agencies more flexibility to report news that shows some disagreements in the region.

The cooperation narrative publicized by the state-run media outlets changed during the 20162017 period and was correlated with a change in Uzbek leadership, which resulted in an increase in reporting of cooperative news stories between Uzbekistan and its neighbours as many positive bilateral actions took place. It is noted, however, that the approach to reporting did not change much, as the national outlet continued to not report any conflict stories, even when such incidents took place.

While the systematic avoidance of reporting regional conflicts by TGA, Khovar, UzA, and the underreporting — in the form of reporting on self only—by Kabar and Kazinform may have created the impression of a more cooperative region; the comparison with RFE/RL's articles allows us to conclude that all Central Asian state-run media outlets underreported regional conflict. Although the underreporting is not measured in avoidance of reporting on a number of conflictive events, it shows the media outlets employing external legitimation strategies to support and sustain their regimes. 


\section{Acknowledgements}

We would like to express much gratitude to the three anonymous peer reviewers of Central Asian Survey whose invaluable comments have greatly contributed toward improving the overall quality of this paper. Our gratitude extends to Jeannette Feuer and David Lampo, who reviewed and edited this paper. This paper utilized data from the Central Asia Watch (CAW)

Project; therefore, we would like to thank the CAW team for their information-gathering and coding efforts. 


\section{References}

Allison, Olivia. 2006. "Selective Enforcement and Irresponsibility: Central Asia's Shrinking Space for Independent Media." Central Asian Survey 25 (1-2): 93-114. doi:10.1080/02634930600903072.

Anceschi, Luca. 2011. "Reinforcing Authoritarianism through Media Control: The Case of PostSoviet Turkmenistan." In After the Czars and Commissars: Journalism in Authoritarian PostSoviet Central Asia, edited by E. Freedman and R. Shafer, 59-77. Eurasian Political Economy and Public Policy Study Series. East Lansing: Michigan State University Press. http://eprints.gla.ac.uk/88140/.

Asian Development Bank. 2019. Promoting Regional Tourism Cooperation Under CAREC 2030: A Scoping Study. Asian Development Bank.

Bajraktari, Yll, and Christina Parajon. 2007. "The Role of the Media in Conflict." United States Institute of Peace, June 1. https://www.usip.org/publications/2007/06/role-media-conflict.

Bichsel, Christine. 2009. Conflict Transformation in Central Asia: Irrigation Disputes in the Ferghana Valley. Central Asia Studies Series 14. Oxon: Routledge.

Burnell, Peter. 2006. "Autocratic Opening to Democracy: Why Legitimacy Matters." Third World Quarterly 27 (4): 545-62. doi:10.1080/01436590600720710.

Callaghan, Karen J., and Frauke Schnell. 2005. Framing American Politics. Pittsburgh, PA: University of Pittsburgh Press.

Cornell, Svante E., and Frederick S. Starr. 2018. Modernization and Regional Cooperation in Central Asia: A New Spring? Central Asia-Caucasus Institute and Silk Road Studies Program. https://www.silkroadstudies.org/resources/1811CA-Regional.pdf.

Cummings, Sally N., ed. 2002. Power and Change in Central Asia. Politics in Asia Series. London: Routledge.

de Vreese, Claes, and Hajo Boomgaarden. 2003. "Valenced News Frames and Public Support for the EU." Communications 28 (4): 361. doi:10.1515/comm.2003.024.

del Sordi, Adele, and Emanuela Dalmasso. 2018. "The Relation between External and Internal Authoritarian Legitimation: The Religious Foreign Policy of Morocco and Kazakhstan.” Taiwan Journal of Democracy 14 (1): 95-116.

Devlet, Nadir. 1997. "Ethnicity and Power: Relations Between the Central Asian States." Perceptions: Journal of International Affairs 2 (1).

Elhance, Arun P. 1997. "Conflict and Cooperation over Water in the Aral Sea Basin." Studies in Conflict \& Terrorism 20 (2): 207-18. doi:10.1080/10576109708436034.

Entman, Robert M. 2004. Projections of Power: Framing News, Public Opinion, and U.S. Foreign Policy. Studies in Communication, Media, and Public Opinion. Chicago: University of Chicago Press.

Entman, Robert M. 2007. "Framing Bias: Media in the Distribution of Power." Journal of Communication 57 (1): 163-73. doi:10.1111/j.1460-2466.2006.00336.x.

Freedman, Eric. 2014. "Barriers to Coverage of Transborder Environmental Issues in the Ferghana Valley of Central Asia." Applied Environmental Education \& Communication 13 (1): 48-55. doi:10.1080/1533015X.2014.914720.

Freedom House. 2017. Freedom of the Press 2017. https://freedomhouse.org/sites/default/files/FOTP_2017_booklet_FINAL_April28.pdf. 
Gavrilis, George. 2017. "Central Asia's Uncertain Radicalization and the Opportunities for the Russia-U.S. Cooperation.” Pathways to Peace and Security 1 (52): 251-60. doi:10.20542/23071494-2017-1-251-260.

Grauvogel, Julia, and Christian von Soest. 2014. "Claims to Legitimacy Count: Why Sanctions Fail to Instigate Democratisation in Authoritarian Regimes." European Journal of Political Research 53 (4): 635-53. doi:10.1111/1475-6765.12065.

Gross, Peter, and Timothy Kenny. 2008. "The Long Journey Ahead: Journalism Education in Central Asia.” Problems of Post-Communism 55 (6): 54-60. doi:10.2753/PPC1075-8216550605.

Hashimova, Umida. 2018. "Central Asian Reset.” Eurasia Daily Monitor, March 21. https://jamestown.org/program/central-asian-reset/.

Heathershaw, John, and Nick Megoran. 2011. "Central Asia: The Discourse of Danger." openDemocracy, June 16. https://www.opendemocracy.net/en/odr/central-asia-discourse-ofdanger/.

Holbig, Heike. 2011. "International Dimensions of Legitimacy: Reflections on Western Theories and the Chinese Experience.” Journal of Chinese Political Science 16 (2): 161-81. doi:10.1007/s11366-011-9142-6.

Horak, Slavomir. 2018. "Central Asia After Astana: From Integration to Cooperation." The Central Asia-Caucasus Analyst, April 30. https://www.cacianalyst.org/publications/analyticalarticles/item/13509-central-asia-after-astana-from-integration-to-cooperation.html.

Isaacs, Rico. 2019. "The Role of Party Interest Articulation in the Personalist-Authoritarian Regimes of the Central Asian Republics of Kazakhstan, Turkmenistan, and Tajikistan." Problems of Post-Communism, August: 1-13. doi:10.1080/10758216.2019.1645606.

Isaacs, Rico, and Alessandro Frigerio, eds. 2019. Theorizing Central Asian Politics: The State, Ideology and Power. International Political Theory. Basingstoke: Palgrave Macmillan.

Jourde, Cédric. 2007. "The International Relations of Small Neoauthoritarian States: Islamism, Warlordism, and the Framing of Stability." International Studies Quarterly 51 (2): 481-503. doi:10.1111/j.1468-2478.2007.00460.x.

Junisbai, Barbara. 2011. "Oligarchs and Ownership: The Role of Financial-Industrial Groups in Controlling Kazakhstan's 'Independent' Media.” In After the Czars and Commissars:

Journalism in Authoritarian Post-Soviet Central Asia, edited by Eric Freedman and Richard Shafer, 35-58. Journalism in Authoritarian Post-Soviet Central Asia. East Lansing: Michigan State University Press. www.jstor.org/stable/10.14321/j.ctt7ztd46.5.

Junisbai, Barbara, Azamat Junisbai, and Nicola Fry. 2015. "Mass Media Consumption in Post-Soviet Kyrgyzstan And Kazakhstan: The View from Below." Demokratizatsiya: The Journal of PostSoviet Democratization 23 (3): 233-56.

Kaminski, Bartlomiej, and Saumya Mitra. 2010. Skeins of Silk: Borderless Bazaars and Border Trade in Central Asia. Washington, DC: World Bank.

Koch, Natalie. 2013. 'Introduction-Field Methods in 'Closed Contexts': Undertaking Research in Authoritarian States and Places.” Area 45 (4): 390-95. doi:10.1111/area.12044.

Krutov, Anatoly, and Max Spoor. 2003. "The 'Power of Water' in a Divided Central Asia." Perspectives on Global Development and Technology 2 (3): 593-614. doi:10.1163/156915003322986415.

Lavrakas, Paul J. Encyclopedia of Survey Research Methods. Thousand Oaks, Calif: SAGE Publications, 2008. 
Mazepus, Honorata, Wouter Veenendaal, Anthea McCarthy-Jones, and Juan Manuel Trak Vásquez. 2016. "A Comparative Study of Legitimation Strategies in Hybrid Regimes." Policy Studies 37 (4): 350-69. doi:10.1080/01442872.2016.1157855.

Megoran, Nick. 2017. Nationalism in Central Asia: A Biography of the Uzbekistan-Kyrgyzstan Border. Central Eurasia in Context Series. Pittsburgh, Pa.: University of Pittsburgh Press.

Menga, Filippo. 2018. Power and Water in Central Asia. Routledge Advances in Central Asian Studies 13. London: Routledge, Taylor \& Francis Group.

Menga, Filippo. 2019. "Researchers in the Panopticon? Geographies of Research, Fieldwork, and Authoritarianism." Geographical Review, October: 1-17. doi:10.1080/00167428.2019.1684197.

Nourzhanov, Kirill. 2018. "Central Asia's Regional Thaw | East Asia Forum.” East Asia Forum, December 22. https://www.eastasiaforum.org/2018/12/22/central-asias-regional-thaw/.

Pak, Mariya, and Kai Wegerich. 2014. "Competition and Benefit Sharing in the Ferghana Valley." Central Asian Affairs 1 (2): 225-46. doi:10.1163/22142290-00102004.

Price, Vincent, David Tewksbury, and Elizabeth Powers. 1997. "Switching Trains of Thought: The Impact of News Frames on Readers' Cognitive Responses." Communication Research 24 (5): 481-506. doi:10.1177/009365097024005002.

Roland, Gérard. 2004. "Understanding Institutional Change: Fast-Moving and Slow-Moving Institutions." Studies in Comparative International Development 38 (4): 109-31. doi:10.1007/BF02686330.

Rollberg, Peter, and Marlene Laruelle. 2015. "The Media Landscape in Central Asia: Introduction to the Special Issue." Demokratizatsiya 23 (3): 227-32.

Rumer, Boris Z. 2002. Central Asia: A Gathering Storm? Armonk, NY: M. E. Sharpe.

Sakeeva, Venera. 2013. "Increasing Human Security to Prevent Water Wars in the Ferghana Valley." Central Asia and the Caucasus 14 (4).

Schatz, Edward. 2009. "The Soft Authoritarian Tool Kit: Agenda-Setting Power in Kazakhstan and Kyrgyzstan.” Comparative Politics 41 (2): 203-22. doi:10.5129/001041509X12911362972034.

Semetko, Holli A., and Patti M. Valkenburg. 2000. "Framing European Politics: A Content Analysis of Press and Television News.” Journal of Communication 50 (2): 93-109. doi:10.1111/j.14602466.2000.tb02843.x.

Shah, Dhavan V., Mark D. Watts, David Domke, and David P. Fan. 2002. "News Framing and Cueing of Issue Regimes: Explaining Clinton's Public Approval in Spite of Scandal.” Public Opinion Quarterly 66 (3): 339-70. doi:10.1086/341396.

Sorbello, Paolo. 2018. "Uzbekistan Makes Up with Tajikistan Over Electricity." The Diplomat, March 12. https://thediplomat.com/2018/03/uzbekistan-makes-up-with-tajikistan-overelectricity/.

von Soest, Christian, and Julia Grauvogel. 2015. "How Do Non-Democratic Regimes Claim Legitimacy? Comparative Insights from Post-Soviet Countries." IDEAS Working Paper Series from RePEc.

Wolf, Aaron T. 1999. "The Transboundary Freshwater Dispute Database Project." Water International 24 (2): 160-63. doi:10.1080/02508069908692153. 


\section{Appendix}

\section{GEOGRAPHIC SCALE}

The geographic scale of the news articles (hereafter referred to as articles) is defined relative to the region of interest - the five countries of Central Asia (CA). CAW distinguishes five geographical scales: domestic (1), regional (2), interregional (3), nonregional (4), or not applicable (99). In this study, we focus on articles with a geographic scale of 2.

According to the Central Asia Watch (CAW) project, an article is coded as regional for scale if it involves at (1) least two of the five CA countries and/or (2) covers an event involving the relationship between at least two CA countries. These may include articles that:

- Feature meetings, competitions, exchanges, trade, infrastructure, border issues, resource sharing, exhibitions, regional sporting events, foreign visits, or cultural events involving two or more CA countries

- Cover natural disasters that occur on the territory of two or more CA states

- Discuss participation in regional meetings, organizations, or events where at least two CA countries are key players, such as EEU/EES, SCO, CICA, CIS, IFAS, SPECA. This includes regional sports organizations and events such as the Asian Football Confederation (AFC) and the Olympic Council of Asia. (Note: this does not include global organizations and events such as the UN, FIFA, and the Olympics unless condition number 2 is met.)

- Include historical notes, such as cooperation between CA republics during WWII, for example.

CAW's automated machine coding algorithm uses a content analysis approach to define the geographic sale of each article. Each time an article mentions at least two of the following root words: 'Kazakh,' 'Kyrgyz,' 'Tajik,' 'Turkmen,' and 'Uzbek,' the computer codes the article 2 for geographic scale. The CAW's automated machine coding algorithm is unable to process images when determining the geographic scale; thus, coding is based on an analysis of the text only, regardless of whether or not a picture is included with the article to provide clarity regarding the geographic scale. In a composite story where multiple geographic scales may apply, regional topics (Scale value of 2) take precedence over others, even if not the primary focus of the article based on the title.

\section{CONFLICT AND COOPERATION SCALE (CCS)}

The regional articles $($ Scale $=2$ ) are classified using CAW's conflict and cooperation scale (CCS). The CCS tracks for verbal and physical events performed by the states or their representatives. All regional articles are classified as conflictive (-), cooperative (+), or neutral (zero). Both conflictive or cooperative articles can be classified as featuring verbal (value of \pm 1 ) or action (value of \pm 2 ) events. Note that articles discussing historical actions are considered as verbal events under the CCS. Additionally, articles that report two or more CCS events are coded for the most recent event (e.g., a border crossing is reopened after being closed). Coding is based on an analysis of the text only, regardless of whether or not a picture is included with the article to provide clarity regarding the CCS. A detailed rubric of the CCS is provided below: 


\section{CAW's CCS}

0 neutral event

-2 conflict action

$-1 \quad$ conflict verbal

1 cooperation verbal

2 cooperation action

99 No Value/CCS does not apply

Neutral $=0$

If an article refers to CA countries in neither positive nor negative terms and it does not make implications for the relationship between two or more CA countries, it is coded as 0 for CCS. Most regional articles will not fall into this category. Some examples of possible cases are described below:

- Accidents: no fault events/natural disasters

- Educational/informational articles

- Commitment to neutrality

- Participation in a sporting event outside of CA

- Information about sports teams/athletes (e.g., a Tajik will be refereeing a Kyrgyz AFC soccer match)

No Value/CCS does not apply $=99$

The CCS only applies to regional articles. All articles in which the geographic scale is not 2 will have a CCS of 99.

Cooperation Action $=+2$

Economic Topics:

- delivering economic or disaster relief aid

- making economic loans or grants

- establishing common transportation or communication networks

- engaging in trade

- easing economic restrictions

- repaying debts

- establishing economic common market

- entering economic pacts

- conducting trade agreements

- granting favoured nation status

- engaging in joint infrastructure development projects

- participating in joint economic ventures

- ensuring delivery of water and energy resources

- reporting of (cumulative) trade numbers: this is considered a cooperative 'act' of trading
Conflict Action $=-2$

Economic Topics:

- physically hindering or impeding trade

- manipulating trade or currency to cause economic problems

- halting/preventing aid

- unilateral construction of infrastructure against another country's protests

- $\quad$ theft

- reducing flow of water or electricity to another country

- building infrastructure to avoid/stop cooperation, e.g., stop sharing existing joint infrastructure 


\begin{tabular}{|c|c|}
\hline $\begin{array}{l}\text { (ignore trade topic if information is } \\
\text { anecdotal or is mentioned as background } \\
\text { information) } \\
\text { - } \quad \text { Government ratifies agreement or bill (i.e., } \\
\text { agreement to aid another CA country) } \\
\text { Diplomatic Topics: } \\
\text { - } \quad \text { increasing (welcomed) official presence in } \\
\text { - } \text { another country } \\
\text { - } \quad \text { foreign visit by a head of state (president) } \\
\text { includes all activities during state visit, } \\
\text { provided there is no conflict } \\
\text { - } \\
\text { signing agreements and other similar } \\
\text { documents } \\
\text { - } \text { making/signing joint statements: a joint } \\
\text { statement is considered an act } \\
\text { - joining or organizing international alliances } \\
\text { - } \quad \text { providing material support } \\
\text { - } \\
\text { refusing sanctuary to foreign opposition } \\
\text { leaders } \\
\text { - }\end{array}$ & $\begin{aligned} \text { Cultural Topics: } \\
-\quad \text { cancelling joint research agreements } \\
-\quad \text { intellectual theft or unauthorized } \\
\text { reproductions } \\
-\quad \text { withdrawing from participation in a } \\
\text { sports or cultural event in or with } \\
\text { another CA country } \\
\text { Security Topics: } \\
-\quad \text { spying on foreign nationals } \\
-\quad \text { hindering movement and activities of } \\
\text { foreign nationals } \\
\text { - closing borders and blocking free } \\
\text { communication (for hostile and } \\
\text { nonhostile/security reasons) } \\
\text { - } \quad \begin{array}{l}\text { executing alleged spies of another } \\
\text { country }\end{array} \\
\text { seizing property of another country }\end{aligned}$ \\
\hline
\end{tabular}




\section{Military Topics:}

- providing air, naval, or land facilities for bases

- giving technical or advisory military assistance

- granting military aid

- intervening with military support at request of government

- concluding military agreements

- training military personnel

- conducting joint military exercises

- disarmament

- establishing joint military efforts

- exchanging prisoners of war

- cease-fires

- peace treaties

- withdrawing troops from the joint border zones

Cooperation Verbal $=+1$

Diplomatic Topics:

- heads of the state meeting under the umbrella of an international organization

- meeting between foreign officials

- written or verbal expression of support

- expressed desire for cooperation

- presentation by diplomats of their letter of credentials

- appointing ambassadors

- requesting support for policy

- announcing intentions to improve relations

- official support of policy

- raising legation to embassy

- reaffirming friendship

- apologizing for unfavourable actions or statements

- resuming broken relations
- expelling or arresting foreign nationals (with or without grounds)

- prosecution/punishment of foreign nationals (with or without grounds)

- increased border controls

- protests expressing sentiment against another country

Military Topics:

- engaging in combat

- annexing territory

- invasion of territory

- increasing troop mobilization at borders

- kidnapping, torturing, or killing of foreign citizens or prisoners of war

- provoking riots, rebellions, or coups

- training or providing aid for rebellions

- encouraging guerrilla activities against foreign country

- $\quad$ sponsoring terrorist actions in another country

Conflict Verbal $=-1$

Verbal statements:

- criticizing foreign policies or actions

- recalling ambassadors

- making retaliation statements

- making threatening demands and accusations

- denouncing foreign leaders, system, or ideology

- cancelling/withdrawing from meetings, conferences, summits, sports events, etc.

- refusing participation in talks, meetings, or summits

- breakdown of negotiations

- implementing propaganda attacks

- issuing diplomatic notes of protest

- cancelling official (nonpresidential) visits

- requesting clarification of another 


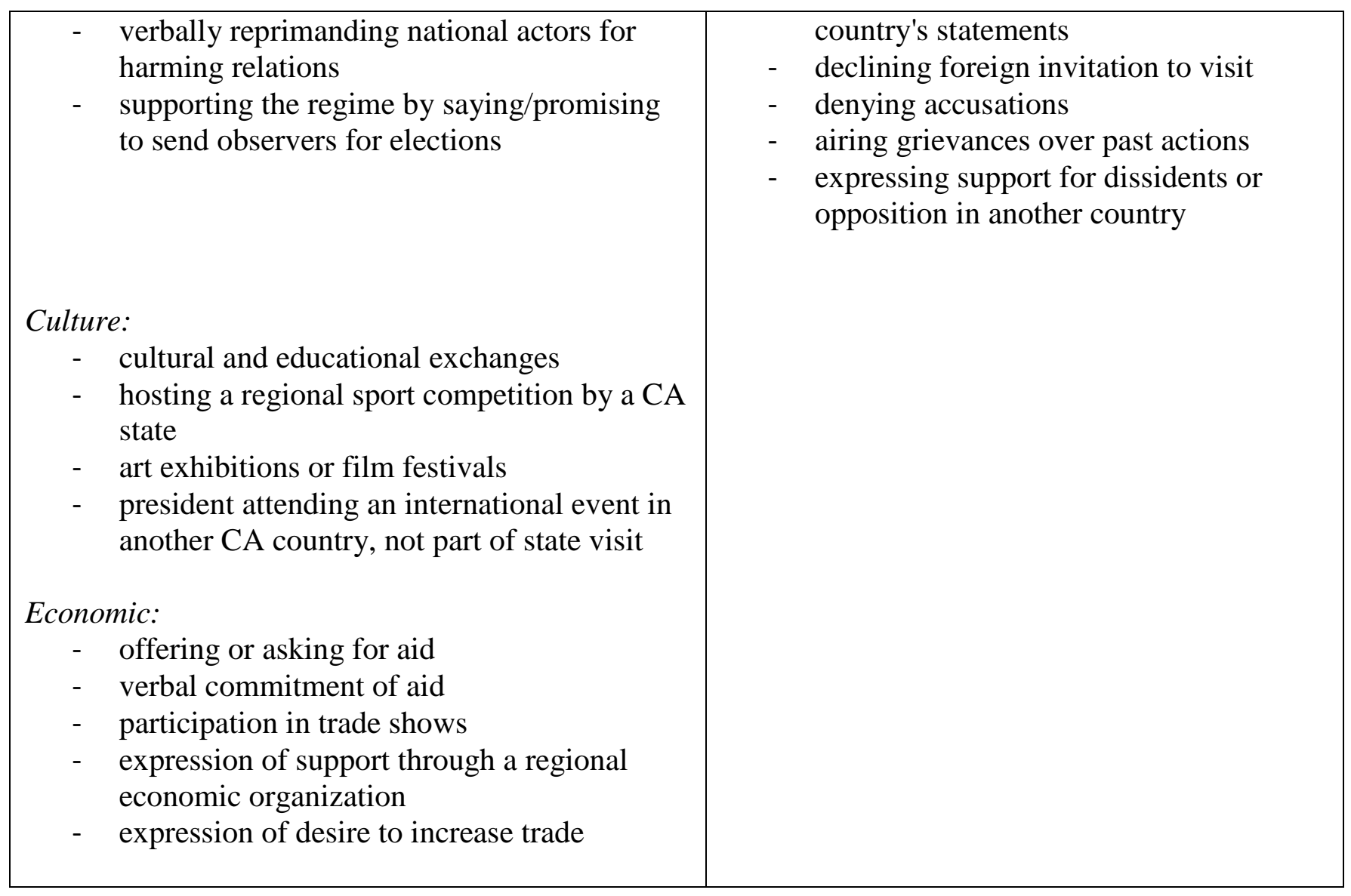

